\title{
Release of Chrysoperla carnea (Stephens) ( Neruoptera : Chrysopidae) as a Biological Control Agent against Tetranychid Mites, Tetranychus urticae (Koch), on Phaseolus vulgaris L. Plantations under Semi Field Conditions. Fatma M. Saleh ; Aliaa A .Tawfik and Merfat K. Elsherbeni Plant Protection Research Institute, ARC, Dokki, Giza, Egypt.
}

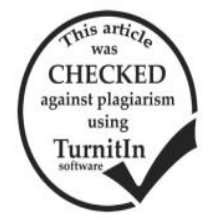

ABSTRACT

This study was outlined to evaluate the effect of releases second larval instar of Chrysoperla carnea (Stephens) at different predators: prey ratios (P:p) to control tetranychid mites on the kidney bean, Phaseolus vulgaris L. plants under semi field conditions during summer 2016. The results revealed that the effective control of Tetranychus urticae Koch was realized after six days from introducing C.carnea larvae when the P: p ratio was 1:10 or 1:20, while at higher ratios (1:40 and1:50), the tetranychid mites numbers decreased after 12 days from the release. The results assured that the numbers of kidney bean tetranychid mites decreased after 6 days from release by 100 and $86.6 \%$ at $1: 10$ and 1:20 P: p ratios, respectively. While the larvae of C.carnea which released after nine days the percentage redaction of T.urticae was 100,100, 93.3,90.2\% and 84.7 days with P:p releases of 1:10, 1:20, 1:30, 1:40 and1:50, respectively. The obtained results showed that the number of tetranychid mites remained zero for a period of 12 days after the release. Regression analysis demonstrated a strong negative relationship between P:p ratios and reduction percentage of the Kidney bean tetranychid mites.

Keywords: Chrysoprela carnea, predator: prey ratio, Tetranychus urticae.

\section{INTRODUCTION}

In recent years, the Kidney bean tetranychid mitesTetranychus urticae koch, (Tetranychidae) has become a serious mites pest of several economic vegetable crops including Kidney bean necessitating the need to investigate the efficacy of the lacewing, Chrysoprela carnea (Steph) as a biological agent against many sucking pests (Cander and Duelli ,1984). The common green lacewing, C. carnea appears to be a good candidate for use in I.P.M programs (Aziz .,2007) . A control option for this insect pests reviewed her includes using $2^{\text {nd }}$ instar larvae of $C$. carnea in an attempt to control T.urticae on Kidney bean in green house.

Methods were used to quantify the effect of predators on T.urticae populations (Rautapaa ,1977 ; Hanafy, 2004, and EL- Masselati et al ,2017). One common technique is to use field cage to enclose known numbers of predatory species with known numbers of mites species.

Therefore, the aims of the current study were to evaluate the optimal predator: prey ratio of second larval instar C. carnea to control T.urticae infesting kidney bean plants under semi field conditions.

\section{MATERIALS AND METHODS}

The experimental traits were conducted at Mansoura district, Dakahlia Governate , during the summer of 2016. The Phaseolus vulgaris L. plants under cages were sprayed with Malathion 57\%. E.C. to kill any insects on the plants before releasing the predators. Two weeks after spraying, plants were infested with two- spotted spider mitesT.urticae (ten females and two males per/pot).Stems of kidney bean plants were ringed with sticky material (Tangle-foot) to prevent mite escape. Kidney bean pots were maintained under a net green house. The aim of this experiment is to study the efficiency of 2nd instar larvae of C.carnea as bio control agent against T.urticae.The second larval instar of C.carnea were obtained from mass rearing unit of the laboratory, which were used for transportation of larvae . After five days kidney bean plants were divided into six treatment groups, each one consists of four replicate pots .The first group of pots was received ten second larval instar of C.carnea per/pots the second group received 20 predators individuals per/pots, the third groups received 30 predators individuals per/pot, the fourth groups received 40 predators individuals per/pot but the fifth group received was 50 predators individuals per/pot. While the sixth group was left without releasing lacewing larvae and served as a control . Both prey and predator individuals were transferred to the kidney bean leaves by using a fine camel hair brush. Counts of motile stages of both T.urticae and C.carnea was estimated in each pot just before predator release and then every 3 days by a special magnified hand lens(20x).

Data analysis:

Tetranychid mites numbers at predator: prey ratios were subjected to one way analysis of variance (ANOVA), and the means separated using Duncan's Multiple Range Test (Costat, 1990). In addition, simple linear regression between predator: prey ratio and reduction percentage was run .The reduction percentage was adjusted to changes in control according to Abbott (1925).

Abbott's formula :

Reduction $\%=\left(1-\frac{n \text { in } \mathrm{T} . \text { after treatment }}{n \text { in Co. after treatment }}\right) * 100$
Where $: \mathrm{n}=$ Insect population, $\mathrm{T}=$ treated, $\mathrm{Co}=$ control

RESULTS AND DISCUSSION

Effective control by the C.carnea larvae of two spotted tetranychid mites populations was achieved after nine days from release of the $2^{\text {nd }}$ larval instar with predator: prey ratios of 1:10 and :20 (Table 1). The reduction percentage of these ratios was 62.5 and 48 after one day, 86.6 and 69.8 after three days, 100 and 86.6 after sex day, 100 and $100 \%$ after nine days, respectively. It was observed that the number of tetranychid mites at these release rate remained 0 for a period of 9 days after release of the predaceous 2nd instar larvae.

When the predator: prey ratios was 1:30, the reduction percentage was 44,62 and 77.9 after one, three and six days 93.3 and $100, \%$ after nine and 12 days from introducing the predators, then the tetranychid mites numbers remained at 0 after 12 days from release. Whereas, at 1:40 and 1:50, the tetranychid mites reduced by 32.6 and 30.4 after one days, 54 and 46.2 after three days, 67.8 and 62.2 after six days 90.2 and $84.7 \%$ after nine day, 99.3 and $98.9 \%$ after 12 days,(Table1) .

Based on these results, effective control of T. urticae was obtained after nine days by introducing $2^{\text {nd }}$ larval instar of the $C$. carnea P:p ratios of 1:10 or 1:20, while at lower ratios $(1: 30 ; 1: 40$ and $1: 50)$ of $C$. carnea larvae, effective 
control was not realized 12 days from release. The statistical analysis showed that there was a significant decrease of the two spotted tetranychid mites numbers of predators as bio control agents to control Aphis gossypii Glov, Myzus persica (Sulzer) . and Bemisia tabaci (Gennadius) in different areas of the world (Ermolaev,2003). Hanafy (2004) studied in Egypt the efficacy of releasing $2^{\text {nd }}$ larval instar of $C$. carnea at different levels (3, 6 and 9 larvae / plant) to control $A$. gossypii , M. persica and B. tabaci attacking cucumber (Medina variety) and came to a similar conclusion with the obtained results in the present study which revealed that there was a positive relationship between the different levels and the reduction percentage of the treated pest . Abd ElSalam et al (2005). recoded that $C$. carnea larvae a predator: prey ratio of 1:15 yielded excellent control of $A$. gossypii with the reduction percentage of $88.3 \%$ after one day from the release.

Table 1. Percentages reduction of $T$. urticae after releaseing the $2^{\text {nd }}$ larval instar of $C$. carnea at different predator: prey ratios under semi field conditions.

\begin{tabular}{lllccc}
\hline $\begin{array}{l}\text { Days after } \\
\text { release }\end{array}$ & $\mathbf{1 : 1 0}$ & $\mathbf{1 : 2 0}$ & $\mathbf{1 : 3 0}$ & $\mathbf{1 : 4 0}$ & $\mathbf{1 : 5 0}$ \\
\hline 1 & 62.5 & 48.0 & 44.0 & 32.6 & 30.4 \\
3 & 86.6 & 69.8 & 62.0. & 54.0 & 46.2 \\
6 & 100 & 86.6 & 77.9 & 67.8 & 62.2 \\
9 & 100 & 100 & 93.3 & 90.2 & 84.7 \\
12 & 100 & 100 & 100 & 99.3 & 98.9 \\
\hline
\end{tabular}

Based on simple linear regression between $\mathrm{P}$ : $\mathrm{p}$ ratios of $2^{\text {nd }}$ larval instar of $C$. carnea and reduction percentage of the tetranychid mites, there were negatively strong relationship after one, three and six days from the release of the $C$. carnea. The regression equations were, $y=66.63$ $0.721 \mathrm{x}, \mathrm{y}=92.67-0.965 \mathrm{x}, \mathrm{y}=107.2 \mathrm{x}+0.966 \mathrm{x}, \mathrm{y}=105.2$ $-0.404 \mathrm{x}$ and, $\mathrm{y}=100.5-0.029 \mathrm{x}$ respectively. The values of $\mathrm{R}^{2}$ were $0.940,0.966,0.981,0.944$, and 0.799 in succession (Fig. 1,2,3,4 and 5). This result closely matches with those Abd El-salam et al (2005) which studied that the regression analysis between P: p ratios of C.carnea to control A.gossypii negatively strong relationship after 1 and 12 days from the release of predators. The reduction rate increased with lower P:p ratios and vice versa.

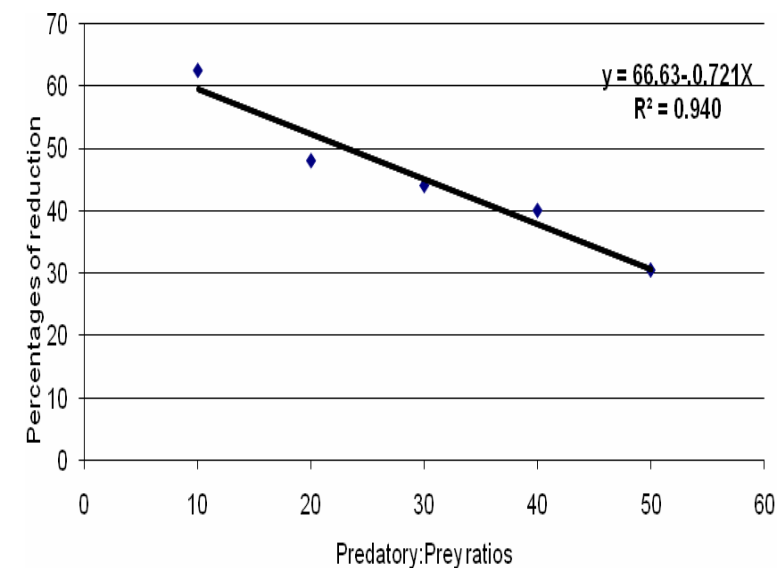

Fig. 1. Simple linear regression between predator: prey ratios $(1: 10)(X)$ and the reduction percentages (Y) of $C$. carnea $2^{\text {nd }}$ instar larvae under semi field conditions.

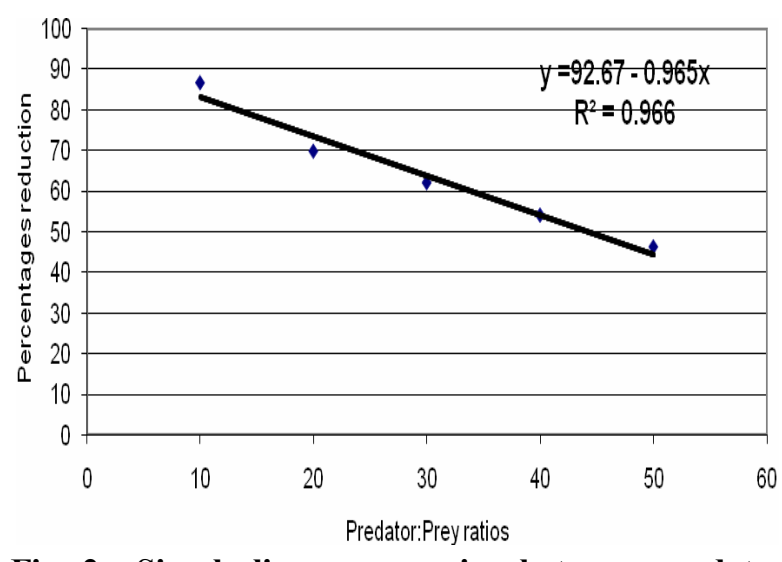

Fig. 2. Simple linear regression between predator: prey $\operatorname{ratios}(1: 20)(\mathrm{X})$ and the reduction percentages $(Y)$ of $C$. carnea $2^{\text {nd }}$ larvae under semi field conditions.



Fig. 3. Simple linear regression between predator: prey ratios(1:30) (X) and the reduction percentages $(\mathrm{Y})$ of $C$. carnea $2^{\text {nd }}$ larvae under semi field conditions.



Fig. 4. Simple linear regression between predator: prey ratios $(1: 40)(\mathrm{X})$ and the reduction percentages $(Y)$ of $C$. carnea $2^{\text {nd }}$ larvae under semi field conditions.

In the check cages (without predator release), the numbers of kidney bean mites per plant increased over the course of the study: 191.9, 283, 510 on days X,Y,and Z,respectively.. Up to $1000 \%$, increasing rate of kidney bean tetranychid mites occurred after 12 days from initial artificial infestation (Fig. 6). The number of mites increased sharply resulting in severe damage to the kidney bean plants. These results confirmed the effect of the predators in suppressing 
the number of Kidney bean tetranychid mites. Based on the regression analysis, there was a highly negative relationship between initial artificial infestation of $T$. urticae and average final of increasing number of the kidney bean tetranychid mites.

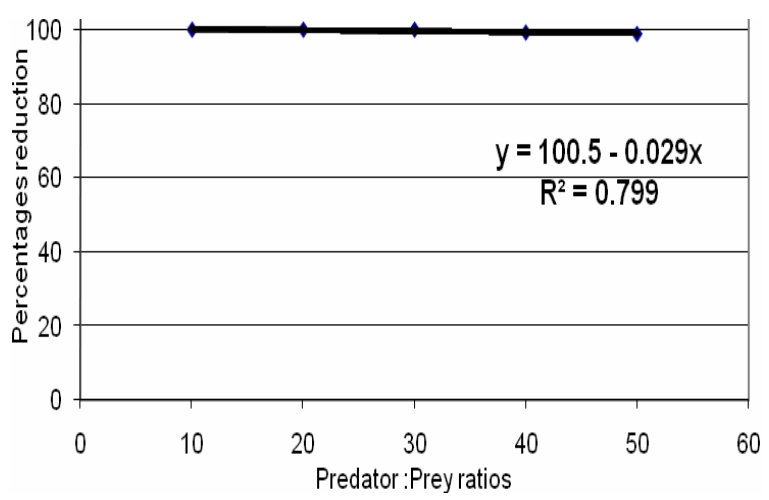

Fig. 5. Simple linear regression between predator: prey ratios $(1: 50)(\mathrm{X})$ and the reduction percentages $(\mathrm{Y})$ of $C$. carnea $2^{\text {nd }}$ instar larvae under semi field conditions.

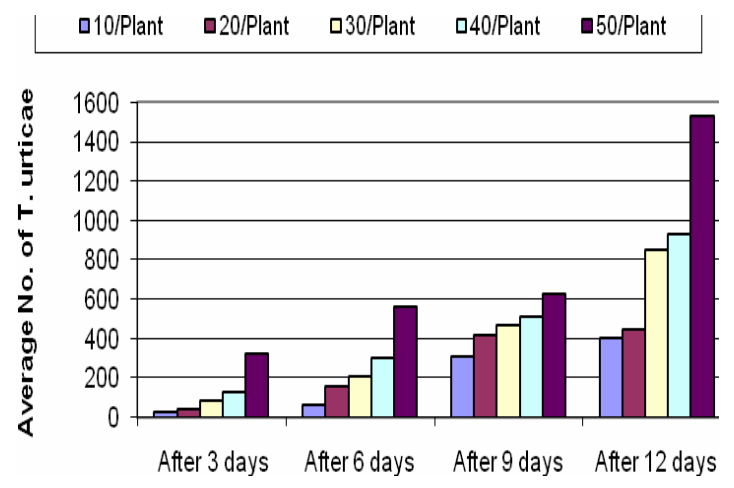

Fig. 6. Average of increasing numbers of $T$. urticaeunder semi field conditions on Kidney bean Plants were initially inoculated with10,20, 30,40 and 50 tetranychid mites/plants.

\section{REFERENCES}

Abbott, W.S. (1925). A method of computing the effectiveness of an insecticide. J. Econ. Entomol.; 18 :265-267.

Abd EL-Salam,A.H.;RAGAB ,M.H.;El-Batran,L. A.(2005). Release of Coccinella undecimpunctata L and Chrysoperla carnea (Steph.) as a biological control tool of the cotton aphid Aphis gossypii GLOVER on tomato plants under field condition . J.Agri., Mansoura Univ .,30(1): 655-669.

Aziza, M. El-Gantiry, S. A. El-Arnaouty, H . M. Badawy and Nevien, M. Gaber. 2007. Biochemical variation in the life stages and populations of Chrysoperla carnea (Stephens) (Neuroptera: Chrysopidae) Egypt J.Agric.Res., 85 (6) : 2121- 2138.

CoStat Software 2004. Microcomputer program analysis Version 4.20, CoHort Software, Berkeley,CA.

Cander,M.andDuelli .p.1984.predatory behavior of larvae and cannibalism .In;M.canard,Y.semeria and T.R.N(editors), Biology of chrysopidae Dr. W. Junk. The Hague,pp.92-100.

Duncan, D. B. 1955. Multiple range and multiple F tests, Biometrics, 11, 1-42.

El-Masselati,H.S.I.,A.A.Hafez;F.F.Shalaby and E.E.Nowar (2017):Using of Chrysoperla Carnea (Stephens) larvae as biological control agent aginst citrus stainton. J.plant Prot.and Phath . Mansoura Univ.Vol.8(7): 333-336

Ermolaev, N. E. 2003. Protection of Capsicum from pests using small-scale technology. Zashchita, Karantin Rastenii. $6: 21-22$.

Hanafy, A. R. I. 2004. Studies on the most important cucumber pests in the open field and suitable control programs. Ph.D Thesis Fac. of Agric. Moshtohor, Benha branch, Zagazig Univ. 219- 228.

Rautapaa, J. 1977.Evaluation of predatory- prey ratio using Chrysoperla carnea (Steph).in control of Rhopalosiphum padi L.Ann.Agric. Fenn. 16 :103-109.

أطلاق المفترسِ اسد المن Chrysoperla carnea (Stephens) كوسيلة مكافحة بيولوجية للعنكبوت الاحمر





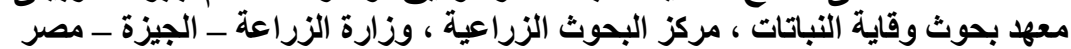

هدفت هذه الدر اسة إلي تقيم تأثير إطلاق كل من يرقات العمر الثانى للمفترس اسد المن وذلك بنسب إطلاق مختلفة لمكافحة



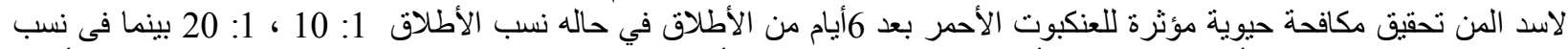

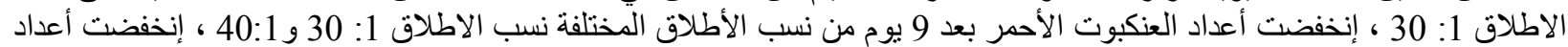

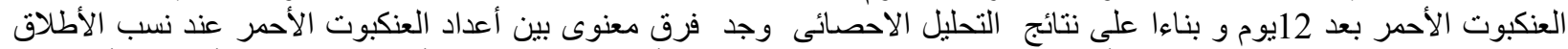

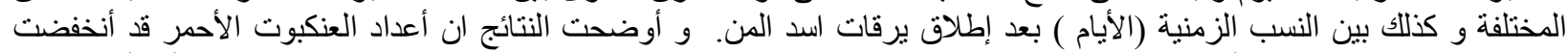

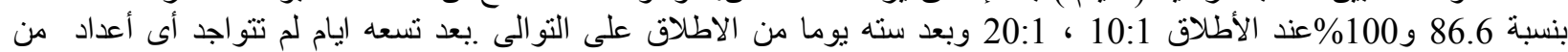

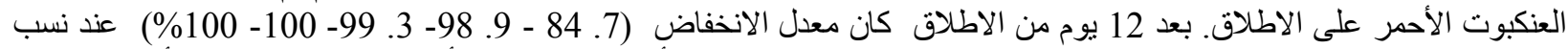

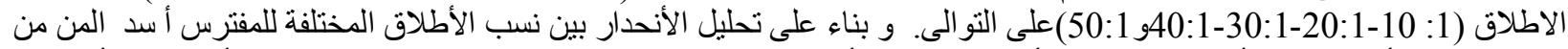

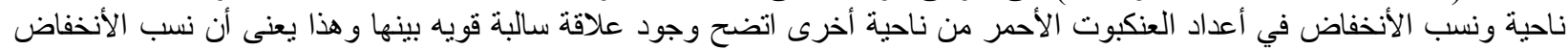



